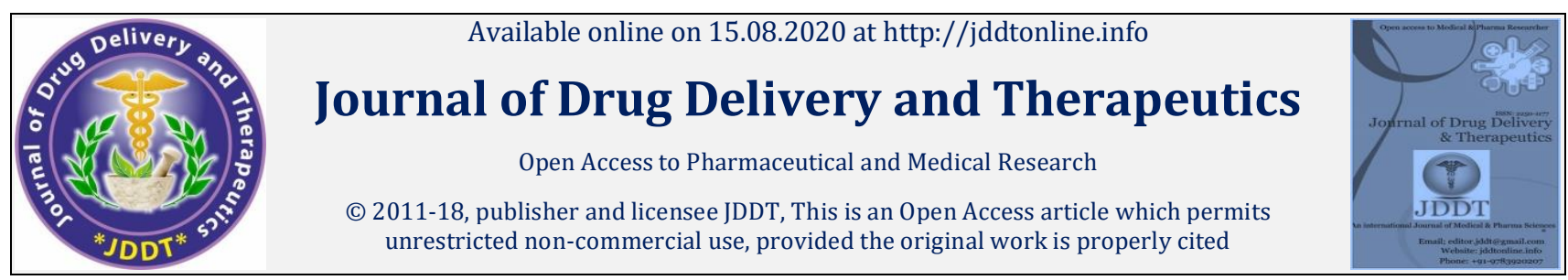

Open $\odot$ Access

Research Article

\title{
Antidiabetic Medicinal Plants Used by the Ethnic People of Devendrakula Velalar in East Coast District of Tamil Nadu, India
}

\author{
Reena Navaroja D ${ }^{1}$, Shanmugam $S^{2 *}$, Rajendran $\mathrm{K}^{2}$ \\ ${ }^{1}$ Post Graduate and Research Department of Botany, Lady Doak College, Tallakulam, Madurai - 625002, Tamil Nadu, India \\ 2 Post Graduate and Research Department of Botany, Thiagarajar College, Teppakulam, Madurai - 625009, Tamil Nadu, India
}

\begin{abstract}
The present study mainly focused on the ethnomedicinal plants used by the Devendrakula Velalar community habiting in selected villages of Pudukkottai, an east coast district of Tamil Nadu, to manage diabetes. Ethnomedicinal data were collected using semi-structured interviews with 18 key informants during July 2019 to January 2020. A total of 22 medicinal remedies prepared from 20 ethnomedicinal plant under 13 families have been documented. Trees are the most common medicinal plants in the study area and leaf is mostly used for the preparation of herbal medicine. The most cited medicinal plant species for the diabetes management is Syzygium cumini with use value of 1.44 . Further phytochemical and pharmacological studies are very essential on such species to validate their efficacy in the management of diabetes.
\end{abstract}

Keywords: Antidiabetic plants, Devendrakula Velalar, Pudukkottai district, Tamil Nadu, Use Value.

Article Info: Received 19 June 2020; Review Completed 24 July 2020; Accepted 07 August 2020; Available online 15 August 2020

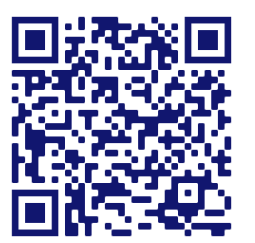

\section{Cite this article as:}

Reena ND, Shanmugam S, Rajendran K, Antidiabetic Medicinal Plants Used by the Ethnic People of Devendrakula Velalar in East Coast District of Tamil Nadu, India, Journal of Drug Delivery and Therapeutics. 2020; 10(4-s):160-165 http://dx.doi.org/10.22270/jddt.v10i4-s.4266

S. Shanmugam, Research Scholar, Post Graduate and Research Department of Botany, Thiagarajar College, 139-140, Kamarajar Road, Teppakulam, Madurai 625009, Tamil Nadu, India.

\section{INTRODUCTION}

Diabetes is an increasingly serious health disorder to the mankind. It is related to other life killing diseases. The management of diabetes is a global problem until now and successful treatment is not yet discovered 1 . All diabetic patients have not got access to modern medicines because of high cost and less availability. Poor sections of diabetic patients are bound to look for medicinal plants as an alternative source of medicine. Recently, there has been a growing interest in the herbal medicine in care and management of diabetes both in developing and developed countries, due to their natural origin and less side effects 2,3 .

Usage of plants as medicine had been a long practice by Devendrakula Velalar popularly called Pallar from ancient times, which is evident from the old literature ${ }^{4}$. This practice of using plants in medicine is still prevailing not only among the Devendrakula Velalar people, but also among several others, who are living in the rural areas of southern part Tamil Nadu. As no such research works have focused on antidiabetic plants in Pudukkottai district of Tamil Nadu, the present study was made to record the most cited ethnomedicinal plants used by the ethnic people of
Devendrakula Velalar community living in Pudukkottai district for diabetes management.

\section{MATERIALS AND METHODS}

\subsection{Geographical profile of study area}

The entire area of Pudukkottai district lies between 78 $25^{\prime}-$ 79o 15' E longitude and 9o 50' - 10 $40^{\prime} \mathrm{N}$ latitude. The district has an area of $4,663 \mathrm{~km}^{2}$ with a coast line of $42 \mathrm{~km}$. It is bounded on the northeast and east by Thanjavur district, on the souhtheast by the Palk Strait, on the southwest by Ramanathapuram and Sivagangai districts, and on the west and northwest by Tiruchirapalli district. The study sites selected for this ethnobotanical investigation viz. Vettanur in Aranthangi taluk, Mavayal, Kidankivayal and Poovalur in Avudaiyarkoil taluk of Pudukkottai district were located at an elevation of $45 \mathrm{~m}$ above $\mathrm{msl}$ and the temperature of the same ranges from $24-38^{\circ} \mathrm{C}$. Annual precipitation averages $550-600 \mathrm{~mm}$. The soil type is loamy sand (sand: $77.6 \%$, silt: $12.4 \%$, clay: $10 \%$ ) with a $\mathrm{pH}$ of about 6.3 . Organic content of the soil is $0.58 \%$. The nitrogen, phosphorus, potassium, calcium and magnesium contents are $0.47 \%, 0.09 \%, 0.38 \%$, $0.60 \%$ and $0.26 \%$ respectively. 


\subsection{About the ethnic people}

Devendrakula Velalar is an ancient group of people belonging to the Marutham land. They are popularly known as Pallar, Mallar, Kudumbar, Vaikaran, Kaladi or Pannadi. They are Tamil speaking community prevalent in Southern India and mostly confined in the southern parts of Tamil Nadu. The term Devendrakula Velalar means "farmer of celestial being" or "farmer of Devendra community" that they are the descendants of Devendran, the god of Marutham land 5. There is literary evidence suggests that Devendrakula Velalar were traditional farmers who produced large quantities of food grains and that were probably rulers in Tamil Nadu 6. The socio-economic position of Devendrakula Velalar as bonded servants working on farms is a central theme of Pallu poetry ${ }^{7}$.

\subsection{Methodology}

The surveys on the traditional application of herbal medicines were conducted during July 2019 to January 2020 in different villages namely Vettanur in Aranthangi taluk, Mavayal, Kidankivayal and Poovalur in Avudaiyarkoil taluk of Pudukkottai district in Tamil Nadu. Ethnobotanical data were collected according to the methodology suggested by Jain ${ }^{8}$, through interviews and discussions with villagers, old age people and herbal healers, those who are having traditional knowledge in medicinal plants. The detailed information about parts used, mode of preparation, form of usage and mixture of other plant products as ingredients were collected. The information gathered was entered in the investigators field note book. The collected plant specimens were botanically confirmed by using regional floras 9,10 and authenticated by verifying with the data pertained in The Plant List 11.

The relative importance of a plant species used as medicine in the study area was calculated with the help of the Use Value (UV) by subjecting the following formula: UV = U / N. Where, $U$ is the number of use-reports cited by each informant for a given plant species and $\mathrm{N}$ is the total number of informants interviewed for a given plant species. Use values are high when there are many use-reports for a plant and low when there are few reports related to its use 12 .

\section{RESULTS AND DISCUSSION}

For this present ethnobotanical study, a total of 18 informants (11 males, 7 females) were interviewed (Fig 1). The male and female ratio was $61.11 \%$ and $38.89 \%$ respectively. It was already reported that in many parts of the world, male rather than female were actively involved in herbal medicine 13 and this statement is concordance with the finding of present study. In this current investigation, the respondents were grouped into three different age categories and most of them (10 individuals) were from the age group of 41 - 60 yrs. It includes 6 males and 4 females (Fig 1). From this, it was clearly known that the elder people have more traditional knowledge on the usage of medicinal plants. The results of present study also revealed that majority of the respondents were mainly agriculturists and in case of herbal healers they were practiced herbal medicine as secondary profession.

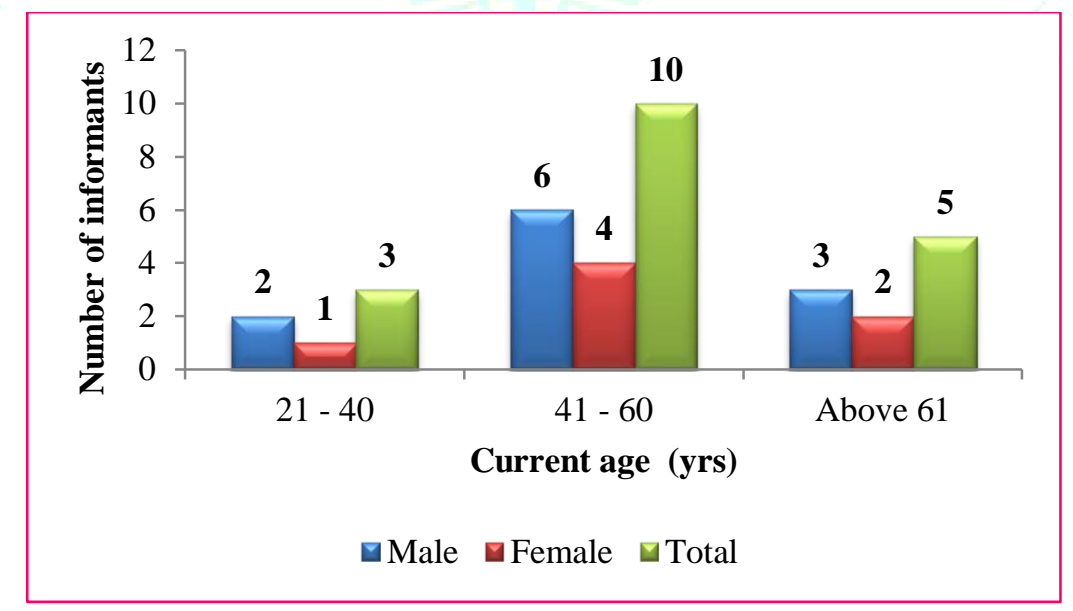

Figure 1: Number of informants in different age group

The present study revealed identification and documentation of 20 medicinal plants belonging to 19 genera and 13 families used by ethnic people of Devendrakula Velalar community for diabetes management with 22 formularies (Table 1). The family Fabaceae was found to be the highest represented family in terms of number of species (4 sp.), followed by Apocynaceae, Cucurbitaceae, Moraceae and Myrtaceae (2 sp. each). The families Acanthaceae, Anacardiaceae, Annonaceae, Combretaceae, Malvaceae,
Meliaceae, Phyllanthaceae and Solanaceae were constitute single species each (Fig 2). The frequent use of plant species of Fabaceae and other dominated families among the ethnic community is a result of diverse wealth of particular plants occurring in the surrounding environments of study sites. Among the antidiabetic plants recorded, Pterocarpus marsupium was categorized as Vulnerable and, Azadirachta indicia and Erythrina variegata as Least Concerned species according to IUCN 14 . 
Table 1: List of antidiabetic medicinal plants with Use Value

\begin{tabular}{|c|c|c|c|}
\hline $\begin{array}{l}\text { Botanical name } \\
\text { (Family name, Vernacular name, Habit) }\end{array}$ & Medicinal use & Citations & $\begin{array}{l}\text { Use } \\
\text { Value }\end{array}$ \\
\hline $\begin{array}{l}\text { Abelmoschus esculentus (L.) Moench (Malvaceae, } \\
\text { Vendai, Herb) }\end{array}$ & $\begin{array}{l}\text { Young fresh fruit is cut into pieces and socked in } \\
\text { cool water. The mucilage like infusion is taken } \\
\text { internally to reduce sugar level }\end{array}$ & 6 & 0.33 \\
\hline $\begin{array}{l}\text { Andrographis paniculata (Burm.f.) Wallich ex } \\
\text { Nees (Acanthaceae, Siriyaanangai, Herb) }\end{array}$ & $\begin{array}{l}\text { Leaf juice is prescribed to drink to reduce sugar } \\
\text { level }\end{array}$ & 12 & 0.66 \\
\hline $\begin{array}{l}\text { Annona squamosa L. (Annonaceae, Seethaa, } \\
\text { Tree) }\end{array}$ & Fruit pulp is eaten raw for reducing sugar level & 7 & 0.38 \\
\hline $\begin{array}{l}\text { Azadirachta indicia A.Juss. (Meliaceae, Vaembu, } \\
\text { Tree) }\end{array}$ & $\begin{array}{l}\text { Tender leaf juice is taken regularly to maintain the } \\
\text { sugar level }\end{array}$ & 9 & 0.50 \\
\hline $\begin{array}{l}\text { Coccinia grandis (L.) Voigt (Cucurbitaceae, Kovai, } \\
\text { Climber) }\end{array}$ & $\begin{array}{l}\text { Unripened fruits are cooked and taken internally to } \\
\text { control sugar level within normal limit }\end{array}$ & 16 & 0.88 \\
\hline $\begin{array}{l}\text { Erythrina variegata L. (Fabaceae, Mullmurungai, } \\
\text { Tree) }\end{array}$ & $\begin{array}{l}\text { Leaf paste mixed with raw rice flour is fried with oil } \\
\text { and eaten to maintain the sugar level }\end{array}$ & 5 & 0.27 \\
\hline Ficus benghalensis L. (Moraceae, Aalam, Tree) & Syrup made from leaves is used to treat diabetes & 3 & 0.16 \\
\hline Ficus racemosa L. (Moraceae, Athi, Tree) & $\begin{array}{l}\text { Root decoction is prescribed for the treatment of } \\
\text { diabetes }\end{array}$ & 2 & 0.11 \\
\hline $\begin{array}{l}\text { Gymnema sylvestre R.Br. (Apocynaceae, } \\
\text { Sirukurinjaan, Climber) }\end{array}$ & $\begin{array}{l}\text { Leaf powder is soaked in water for overnight and } \\
\text { filtrate is taken orally for reduce sugar level }\end{array}$ & 15 & 0.83 \\
\hline Mangifera indica L. (Anacardiaceae, Maa, Tree) & $\begin{array}{l}\text { Kernels are eaten raw to control sugar level within } \\
\text { normal limit }\end{array}$ & 11 & 0.61 \\
\hline $\begin{array}{l}\text { Momordica dioica Roxb. ex. Willd. } \\
\text { (Cucurbitaceae, Pazhupaakhal, Climber) }\end{array}$ & $\begin{array}{l}\text { Young fruits are shallow fried and eaten once in } \\
\text { three days for maintain sugar level }\end{array}$ & 17 & 0.94 \\
\hline $\begin{array}{l}\text { Phyllanthus emblica L. (Phyllanthaceae, Nelli, } \\
\text { Tree) }\end{array}$ & $\begin{array}{l}\text { Fruit juice is taken internally for the treatment of } \\
\text { diabetes }\end{array}$ & 13 & 0.72 \\
\hline Psidium guajava L. (Myrtaceae, Koyyaa, Tree) & $\begin{array}{l}\text { Unripened fruit is eaten raw to reduced sugar level } \\
\text { Leaf powder mixed with fenugreek seed powder is } \\
\text { soaked in water overnight and the filtrate is taken } \\
\text { regularly to maintain the sugar level }\end{array}$ & $\begin{array}{l}10 \\
(8+2)\end{array}$ & 0.55 \\
\hline $\begin{array}{l}\text { Pterocarpus marsupium Roxb. (Fabaceae, } \\
\text { Vaengai, Tree) }\end{array}$ & $\begin{array}{l}100 \mathrm{~g} \text { of young twigs are boiled in } 500 \mathrm{ml} \text { of water } \\
\text { and the decoction is taken internally for } 45 \text { days for } \\
\text { diabetes }\end{array}$ & 6 & 0.33 \\
\hline $\begin{array}{l}\text { Senna auriculata (L.) Roxb. (Fabaceae, Aavaarai, } \\
\text { Shrub) }\end{array}$ & $\begin{array}{l}\text { Flower powder mixed with fenugreek seed powder } \\
\text { and soaked with cool water for overnight. Then } \\
\text { filtrate is taken internally to maintain sugar level }\end{array}$ & 17 & 0.94 \\
\hline $\begin{array}{l}\text { Solanum trilobatum L. (Solanaceae, } \\
\text { Thoodhuvalai, Climber) }\end{array}$ & $\begin{array}{l}\text { Young fruits are shallow fried and are taken once in } \\
\text { three days for maintain sugar level }\end{array}$ & 8 & 0.44 \\
\hline $\begin{array}{l}\text { Syzygium cumini (L.) Skeels (Myrtaceae, Naaval, } \\
\text { Tree) }\end{array}$ & $\begin{array}{l}\text { Ripened fruits are eaten raw to control sugar level } \\
\text { within normal limit Seed powder is soaked in water } \\
\text { overnight and the filtrate is taken regularly to } \\
\text { maintain the sugar level }\end{array}$ & $\begin{array}{l}26 \\
(12+14)\end{array}$ & 1.44 \\
\hline $\begin{array}{l}\text { Terminalia arjuna (Roxb.) Wight \& Arn. } \\
\text { (Combretaceae, Marudhu, Tree) }\end{array}$ & $\begin{array}{l}\text { 3-6 g of stem bark powder is given to drink along } \\
\text { with milk at } 2 \text { hrs after food to maintain the sugar } \\
\text { level }\end{array}$ & 4 & 0.22 \\
\hline $\begin{array}{l}\text { Trigonella foenum-graecum L. (Fabaceae, } \\
\text { Vendhayam, Herb) }\end{array}$ & Leaves are taken as a salad to maintain sugar level & 11 & 0.61 \\
\hline $\begin{array}{l}\text { Wattakaka volubilis (L.f.) Stapf. (Apocynaceae, } \\
\text { Perukurinjaan, Climber) }\end{array}$ & $\begin{array}{l}\text { A teaspoonful leaf powder mixed with honey is } \\
\text { taken internally for maintenance of glucose level }\end{array}$ & 8 & 0.44 \\
\hline
\end{tabular}




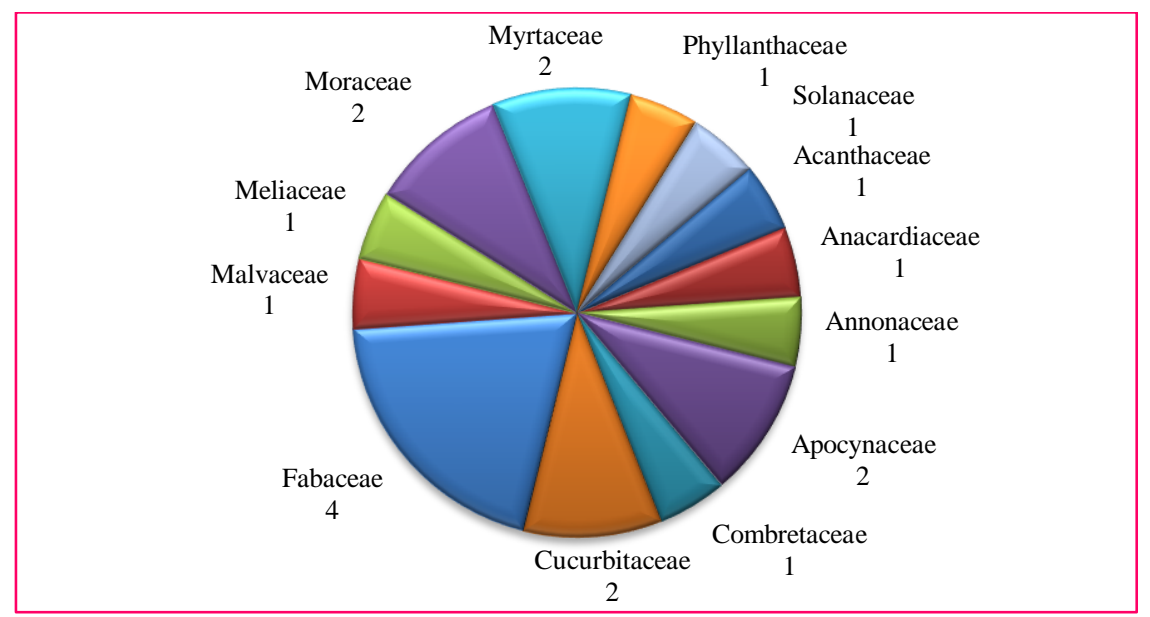

Figure 2: Number of species in each family

Life form evaluation showed that the reported plants were mostly trees (11 sp., 55\%), followed by climbers (5 sp., 25\%), herbs (3 sp., 15\%) and shrub (1 sp., 5\%) (Fig 3). Several studies reported that herbaceous medicinal plants were mostly used in the treatment of human ailments 15-19, because of their wide range of bioactive components ${ }^{20}$. But in present study, trees were found as most commonly used life form among the antidiabetic plants reported from study sites. There are some reports highlighted that trees are preferably used as medicine by the traditional healers 1,21 , which were supported by our study and from this, it was cleared that trees are not only serve timber for mankind and also as good source of medicine.

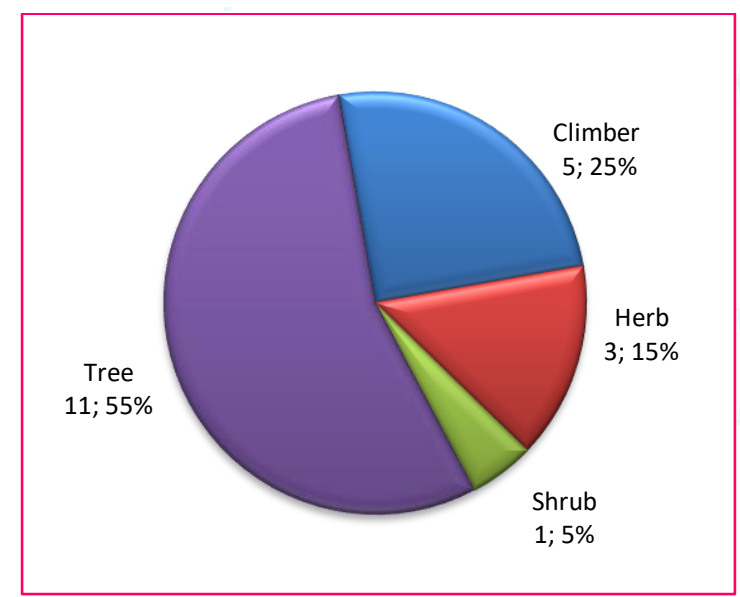

Figure 3: Number and percent distribution of plants in various life forms

With respect to the parts used for the preparation of medicine, the study showed that leaves were found to be most frequently utilized plant part $(36.38 \%)$, followed by fruits $(31.84 \%)$. The other parts viz. flower, fruit pulp, kernel, root, seed, stem bark and twig were provided least contribution (4.54\% each) (Fig 4). The predominant use of leaf used by the folk medicinal practitioners for different therapies has been attested by several studies 22-24. The reason behind the extensive use of leaves is, they were active in photosynthesis which leads the production of secondary metabolites in high concentration when compare to other parts of the plants and these metabolites are actively implicates in remedial activity $22,25,26$.

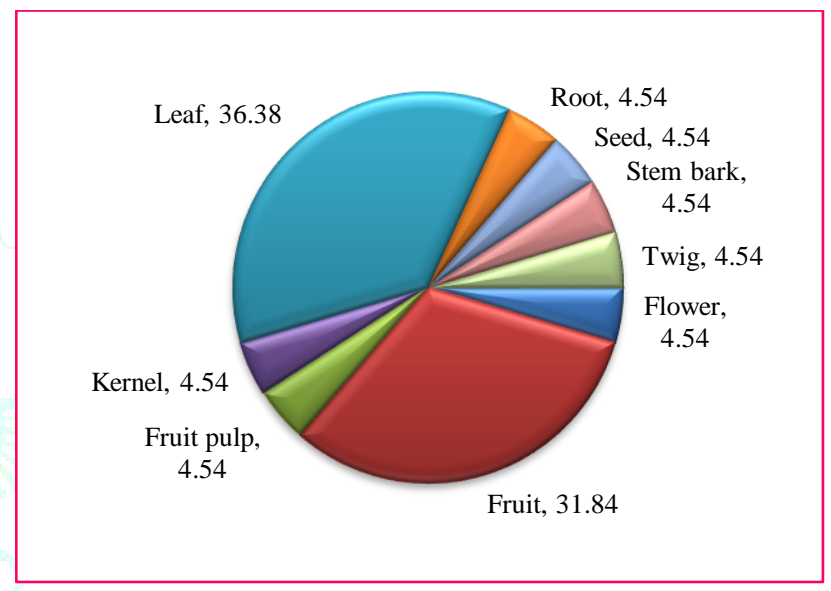

Figure 4: Percent distribution of plant parts used

Among the modes of preparation of herbal medicines, the majority of the plant remedies was prescribed as powder $(27.28 \%)$, followed by raw (18.18\%), juice (13.64\%), cook (13.64\%) and decoction (9.10\%). The least form $(4.54 \%)$ of medicinal preparation was infusion, paste, salad and syrup (Fig 5). These observations are in accordance with the results of most of the previous studies conducted in Tamil Nadu 22,27-29. An ethnobotanical study carried out in Tamil Nadu ${ }^{30}$ showed that paste was the frequently used mode of preparation, which was found inconsistent with the present study.

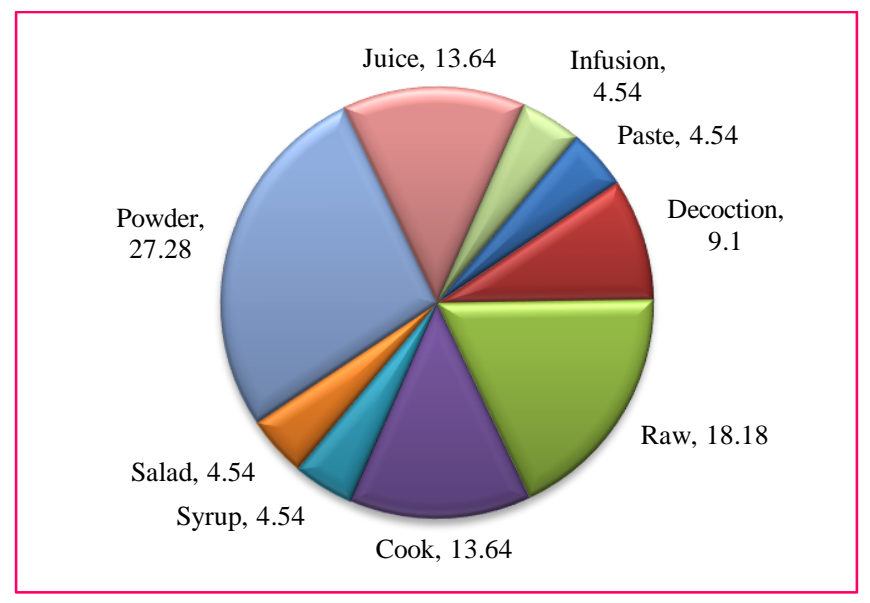

Figure 5: Percent distribution of mode of preparation 
In terms of administration, drink was found as the principal mode of intake of medicine $(59.10 \%)$, followed by eat $(0.90 \%)$ for the treatment of diabetes among the respondents of the study area (Fig 6). It was noted that, the rural people of the study area often mix fenugreek seed for preparation of medicine, and sometimes milk or honey is added as an ingredient to increase the viscosity of the preparation (Table 1). The reason behind this is, the use of remedies prepared from multiple plant products and other materials could be attributed to the belief of more healing power 24,31 .

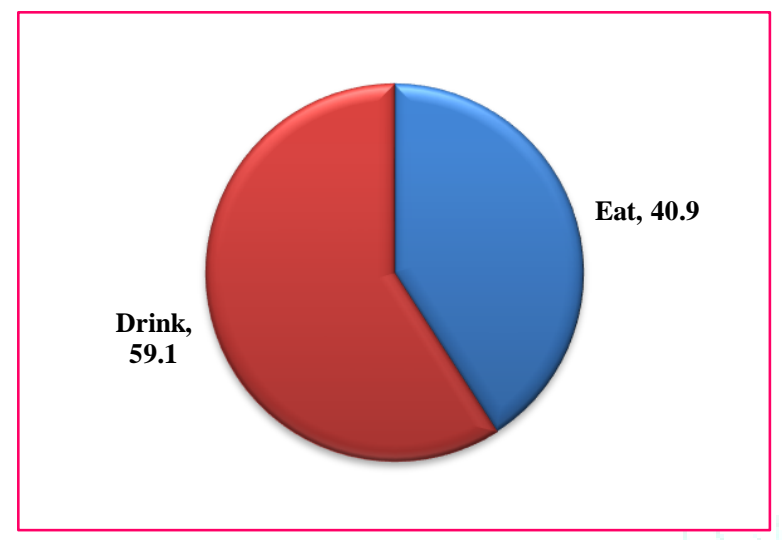

Figure 6: Percent distribution of mode of administration

By this investigation, it was also noted that the medicinal plants used for diabetes management are not equally important. Some species are more important than others among the respondents. The species which is mostly cited for particular purpose by the community people are considered as popular species. According to Use Value analysis, the most cited medicinal plant species for the diabetes management is Syzygium cumini with use value of 1.44 by 26 citations. It is followed by Senna auriculata (use value: 0.94, citations: 17), Momordica dioica $(0.94,17)$, Coccinia grandis $(0.88,16)$, Gymnema sylvestre $(0.83,15)$, Phyllanthus emblica $(0.72,13)$ Andrographis paniculata $(0.66,12)$, Mangifera indica $(0.61$, $11)$ and Trigonella foenum-graecum $(0.61,11)$. The less important species prescribed for the treatment of diabetes among the rural people of study sites is Ficus racemosa with 0.11 use value by only 2 citations (Table 1 ). Maximum citations for a particular species are the indication of such ethnomedicinal plants had good candidate for further phytochemical and pharmacological studies to find new compounds.

\section{CONCLUSION}

The information generated from the present study regarding the medicinal plants may be helpful in formulating the conservation strategies by the government authorities and the concerned Non-Government Organizations. Creating awareness among the local people regarding the conservation of these medicinal plants will be successful and easy if the potential of the medicinal plants, which are used by them, are clearly explained to them. Moreover, all the traditional and cultural knowledge need to be appreciated and should be integrated with the modern scientific techniques and methods while planning any programme for the conservation of biodiversity.

Nowadays, many farmers have already started the cultivation of medicinal plants in their farmland with limited knowledge of organic cultivation. So that conversations should be made with farmer related to organic cultivation using suitable biofertilizers. It will lead the sustainable yield of medicinal plants and increase their marketing values.
The findings this study also provides baseline data to establish a connection between the traditional health practitioners and scientific communities, which could be substantial in novel drug discovery. Therefore, further phytochemical and pharmacological studies are very essential on these medicinally important species to prove their efficacy in the management of diabetes.

\section{ACKNOWLEDGEMENT}

The authors are grateful to the informants of Devendrakula Velalar in various study sites of Pudukkottai district for their contribution and valuable informations on traditional usage of medicinal plants.

\section{CONFLICT OF INTEREST}

The authors have declared that there is no conflict of interest.

\section{REFERENCES}

1. Uddin MZ, Mitu FY, Rifat AB \& Kaium AL. Ethnomedicinal study focusing on anti-diabetic plants used by the community living in and around Dhaka. Bangladesh Journal of Plant Taxonomy, 2019; 26(2):231-247.

2. Modak M, Dixit P, Londhe J, Ghaskadbi S, Paul A \& Devasagayam $\mathrm{T}$. Indian herbs and herbal drugs for the treatment of diabetes. Journal of Clinical Biochemistry and Nutrition, 2007; 40: 163-173.

3. Hasani-Ranjbar S, Larijani B \& Abdollahi MA. A systematic review of the potential herbal sources of future drugs effective in oxidant-related diseases. Inflammation \& Allergy - Drug Targets, 2009; 8:2-10.

4. Subrahmanian N. Sangam Polity: The administration and social life of Sangam Tamils ( $3^{\text {rd }}$ Edition). Ennes Publications, Udumalaipettai, Tamil Nadu, 1996; p. 425.

5. Venkatasubramanian T. Societas to Civitas. Kalinga Publication Press, 1993; p. 74.

6. Ramaiah A. Untouchability and Inter-Caste relations in Rural India: The case of Souther Tamil villages. Journal of Religious Culture, 2004; 70: 1-13.

7. Gnanasekaran T. Pallu Ilakkiya Thirattu. Sahitya Akademi Publications, 2013; p. 192.

8. Jain SK. Method and Approaches in Ethnobotany. Society of Ethnobotanists, CDRI, Lucknow, 1989.

9. Gamble JS \& Fischer CEC. The Flora of the Presidency of Madras (Reprint Edited), Vols. I - III. Botanical survey of India, Calcutta, India, 1957.

10. Matthew KM. An Excursion Flora of Central Tamil Nadu. Oxford and IBH Publishing Co. Pvt. Ltd., New Delhi, India, 1991.

11. The Plant List. A working list of plant species, version 1. www.theplantlist.org. Accessed July 21, 2020.

12. Trotter R \& Logan M. Informant consensus: a new approach for identifying potentially effective medicinal plants. In: Etkin NL, editor. Plants in indigenous medicine and diet: Biobehavioral approaches. Bedford Hills, Redgraves publishers, New York, 1986.

13. Sharanappa R \& Vidyasagar GM. Documentation of traditional knowledge on medicinal plants used in treating candidiasis in Hyderabad Karnataka region, India. World Journal of Pharmacy and Pharmaceutical Sciences, 2014; 3(7):739-751.

14. IUCN (International Union for Conservation of Nature). The Red List of Threatened Species (version 3.1). www.iucnredlist.org. Accessed July 21, 2020.

15. Shanmugam S, Ramar S, Ragavendhar K, Ramanathan R \& Rajendran K. Plants used as medicine by Paliyar tribes of Shenbagathope in Virudhunagar district of Tamil Nadu. Journal of Economic and Taxonomic Botany, 2008; 32(4):922-929.

16. Shanmugam S, Annadurai M \& Rajendran K. Ethnomedicinal plants used to cure diarrhea and dysentery in Pachalur hills of Dindigul district in Tamil Nadu, Southern India. Journal of Applied Pharmaceutical Sciences, 2011a; 1(8):94-97.

17. Shanmugam S, Kalaisevan M, Selvakumar $P$, Suresh K \& Rajendran K. Ethnomedicinal pants used to cure diarrhea and dysentery in Sivagangai district of Tami Nadu, India. International Journal of Research in Ayurveda and Pharmacy, 2011b; 2(3):991-994. 
18. Shanmugam S, Rajendran K \& Suresh K. Traditional uses of medicinal plants among the rural people in Sivagangai district of Tamil Nadu, Southern India. Asian Pacific Journal of Tropical Biomedicine, 2012a; 2:S429-S434.

19. Shanmugam S, Balamurugan S, Pandiselvam P \& Rajendran K. Medicinal plants used by the people of Thiruppuvanam and its surrounding areas of Sivagangai district in Tamil Nadu, Southern India. Journal of Basic and Applied Biology, 2012b; 6:39-45.

20. Gazzaneo LRS, Lucena RFP \& Albuquerque UP. Knowledge and use of medicinal plants by local specialists in a region of Atlantic Forest in the state of Pernambuco. Journal of Ethnobiology \& Ethnomedicine, 2005; 1:9.

21. Uniyal SK, Singh KN, Jamwal P \& Lal B. Traditional use of medicinal plants among the tribal communities Chhota Bhangal, Western Himalaya. Journal of Ethnobiology \& Ethnomedicine, 2006; 2:14.

22. Shanmugam S, Rajagopal V \& Rajendran K. Multipurpose usable plants in Thalaiyanai hills of Tirunelveli forest division in southern part of Western Ghats. Journal of Non-Timber Forest Products, 2007; 14(4):297-306.

23. Shanmugam S, Manikandan K \& Rajendran K. Ethnomedicinal survey of medicinal plants used for the treatment of diabetes and jaundice among the villagers of Sivagangai district, Tamil Nadu. Ethnobotanical Leaflets, 2009; 13:186-193.

24. Shanmugam S, Jeyaprabakaran G \& Rajendran K. Medicinal trees from home gardens of urban areas in Madurai district of Tamil Nadu, Southern India. Asian Journal of Ethnobiology, 2020; 3(1):10-15.
25. Ghorbani A. Studies on pharmaceutical ethnobotany in the region of Turkmen Sahra North of Iran (Part 1): General results. Journal of Ethnopharmacology, 2005; 102:58-68.

26. Ayyanar M, Sankarasivaraman K \& Ignacimuthu S. Traditional herbal medicines used for the treatment of diabetes among two major tribal groups in South Tamil Nadu, India. Ethnobotanical Leaflets, 2008; 12:276-280.

27. Sandhya B, Thomas S, Isabel W \& Shenbagarathai R. Ethnomedicinal plants used by the Valaiyan community of Piranmalai hills (Reserved forest), Tamil Nadu, India - A pilot study. African Journal of Traditional, Complementary and Alternative Medicines, 2006; 3:101-114.

28. Rajendran $\mathrm{K}$ \& Gunasekaran $\mathrm{T}$. Common and cultivated medicinal plants and their utilization by villagers in southern district of Tamil Nadu. The Indian Forester, 2006; 132(12):16311637.

29. Rajendran K, Balaji P \& Jothibasu M. Medicinal plants and their utilization by villagers in Southern districts of Tamil Nadu. Indian Journal of Traditional Knowledge, 2008; 7(3):417-420.

30. Parthiban R, Vijayakumar S, Prabhu S \& Morvin Yabesh JGE. Quantitative traditional knowledge of medicinal plants used to treat livestock diseases from Kudavasal taluk of Thiruvarur district, Tamil Nadu, India. Revista Brasileira de Farmacognosia, 2016; 26:109-121.

31. Giday M, Asfan Z \& Wolduh Z. Medicinal plants of the Meinit group of Ethiopia - an ethnobotanical study. Journal of Ethnopharmacology, 2010; 124(2):513-523. 